\title{
Oxygen and sulphur isotopes of gypsum from the Mogilno Salt Dome cap-rock (Central Poland)
}

\author{
Joanna JAWORSKA and Paweł WILKOSZ
}

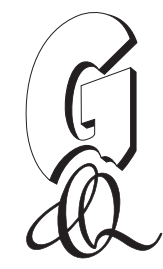

Jaworska J. and Wilkosz P. (2012) - Oxygen and sulphur isotopes of gypsum from the Mogilno Salt Dome cap-rock (Central Poland). Geol. Quart., 56 (2): 249-260, doi: 10.7306/gq.1019

The stable-isotope compositions of oxygen and sulphur from 30 gypsum samples obtained from three drill cores of the Mogilno Salt Dome cap-rock have been analysed; the Mogilno Salt Dome itself is composed of Zechstein evaporites. $\delta^{34} \mathrm{~S}$ values were measured for $\mathrm{SO}_{4}$ ions, whereas $\delta^{18} \mathrm{O}$ values were measured for $\mathrm{SO}_{4}$ and $\mathrm{H}_{2} \mathrm{O}$. For the analyses, bulk samples of gypsum $\left(\mathrm{CaSO}_{4} \cdot 2 \mathrm{H}_{2} \mathrm{O}\right)$ and its dehydrated equivalents $\left(\mathrm{CaSO}_{4}\right)$ were used. The $\delta^{18} \mathrm{O}$ and $\delta^{34} \mathrm{~S}$ values in $\mathrm{SO}_{4}$ were analysed using a direct method, but the $\delta^{18} \mathrm{O}$ value in $\mathrm{H}_{2} \mathrm{O}$ (water of crystallisation) was determined using an indirect method, which influenced the results. The $\mathrm{SO}_{4}$ appeared to be distinctly enriched in heavy oxygen $\left(\delta^{18} \mathrm{O}=11.0-14.6 \%\right)$, which shows that the Zechstein sea was the source of the sulphate; the $\delta^{34} \mathrm{~S}$ values $\left(10.9-13.6 \%\right.$ ) support this conclusion. Variable $\delta^{18} \mathrm{O}$ values of the water of crystallisation $(-11.3$ to $10.7 \%$ ) indicate that diagenetic (hydration) processes affected the various samples. Accessory minerals occurring in gypsum probably also influenced the $\delta^{18} \mathrm{O}$ values. Five groups of gypsum are distinguished: (1) gypsum in which the $\delta^{18} \mathrm{O}$ values of the $\mathrm{H}_{2} \mathrm{O}$ are less than $-10.2 \%$ (this gypsum recrystallised in the presence of water enriched in light oxygen isotopes), (2) gypsum in which the $\delta^{18} \mathrm{O}$ values of $\mathrm{H}_{2} \mathrm{O}$ range between -6.6 and $-4.4 \%$ (interpreted as gypsum in equilibrium with water from the cap-rock), (3) gypsum in which the $\delta^{18} \mathrm{O}$ value of the $\mathrm{H}_{2} \mathrm{O}$ amounts to $10.7 \%$ (anhydrite-bearing sandstone near the salt mirror), (4) gypsum in which the $\delta^{18} \mathrm{O}$ value of the $\mathrm{H}_{2} \mathrm{O}$ ranges between -3.4 and $1.8 \%$ (samples contaminated by anhydrite; the real $\delta^{18} \mathrm{O}$ content is unknown), and (5) gypsum in which the $\delta^{18} \mathrm{O}$ value of the $\mathrm{H}_{2} \mathrm{O}$ ranges between -8.7 and $-6.9 \%$ (interpreted as gypsum with a mixed isotopic composition due to mixing of water from cap-rock and water enriched in light isotopes of oxygen: recent meteoric water or postglacial water?, or as gypsum formed in a warm interval when the groundwater was somewhat enriched in heavy isotopes of oxygen if compared with the groundwater at present).

Joanna Jaworska, Institute of Geology UAM, Maków Polnych 16, 61-606 Poznań, Poland, e-mail: veronika@amu.edu.pl; Pawel Wilkosz, Investgas S.A., Al. Jana Pawła II 70,00-175 Warszawa, Poland, e: mail: pawel.wilkosz@investgas.pl(received: April 13, 2011, accepted: January 19, 2012; first published online: April 26, 2012).

Key words: gypsum, oxygen isotopes, sulphur isotopes, cap-rock, Zechstein, Mogilno Salt Dome.

\section{INTRODUCTION}

Salt diapirs have been the objects of salt mining since the 19th century, but only during the past 30 years they have been investigated and explored in detail as potential hosts for a repository for all kinds of radioactive waste as well as for underground storage of oil and gas by the petroleum industry (Jackson and Seni, 1984; Kreitler et al., 1985; Posey and Kyle, 1988; Werner et al., 1988; Bornemann and Bräuer, 1999; Klinge et al., 2002; Brewitz and Rothfuchs, 2007).

Cap-rocks cover the tops of salt domes; they are integral parts of the salt bodies, being the products of a sequence of processes near the salt mirror, on top of the salt diapirs. In this salt-dissolution zone, salt rock comes in contact with fresh water or just an $\mathrm{NaCl}$-undersaturated solution, and the rock salt becomes dissolved. Rock salt always contains some impurities: anhydrite (in particular), and locally carbonates (calcite, dolomite, magnesite), clay minerals and ferrous compounds. All this material, being less soluble, is left on top of the salt body; in the course of time, it becomes compacted and transformed into a rocky cover, the so-called cap-rock. The main diagenetic process is the hydration of anhydrite, transforming it into gypsum, so that a salt body is often covered by a gypsiferous cap-rock.

Some of the cap-rocks have a long-lived diagenetic history, e.g., surface exposure and erosion, fracturing, internal circulation of meteoric water or hydrothermal fluids, metasomatism, and glaciation (Posey and Kyle, 1988; Prikryl et al., 1988; Werner et al., 1988; Jaworska and Ratajczak, 2008). A key for understanding this history might be a study of the isotopic composition of the sulphates and water of crystallisation that built the gypsum (gypsiferous cap-rock). Isotopic analyses commonly provide information about the conditions and the stages of hydration of the sulphates (Pierre and Fontes, 1978; Hałas 
and Krouse, 1982; Kasprzyk and Jasińska, 1998; Peryt et al., 2002) and may, in the case of cap-rock, help to reconstruct the processes that have occurred near the salt mirror, particularly the water/sulphates interactions. Examples of such investigations are the studies of the Gyp Hill and Oakwood Domes in Texas (Kreitler and Dutton, 1983) and the Wapno Salt Dome in Poland (Jaworska, 2010).

One of the greatest hazards in mines, including salt mines, are inflows of water; cap-rock, being a cover of the salt body, tends to protect the salt quite well against erosion and groundwater, but not always. Inflow may occur particularly when the cap-rock is partly damaged, by nature or by human activity (see Zuber et al., 2000). The results of cap-rock research should be taken into consideration when deciding about the positioning in a salt structure of a salt mine, a repository for radioactive waste or a facility for underground storage of oil or gas.

The purpose of this research was to analyse the $\delta^{18} \mathrm{O}$ layout of the crystalisation water of a cap-rock gypsum and assess whether the $\delta^{18} \mathrm{O}$ value the same over in the whole cap-rock section or whether it shows different values for different levels. The answer to this question has practical means:

- similar $\delta^{18} \mathrm{O}$ values can indicate intense fracturing/karst formation of the cap-rock, subterranean/ground/subsurface water penetration through it and isotopic exchange between the gypsum crystallisation water and the water from the fractures, resulting in isotopic equilibration;

- variable values of the $\delta^{18} \mathrm{O}$ isotope compositions of gypsum crystallisation water may indicate multi-stage cap-rock genesis. It also allows determination of the type of water with which sulphates forming individual cap-rock parts had contact with.

\section{GEOLOGY}

Salt domes belong to the most characteristic structural elements of the Zechstein deposits in the Polish Basin (Fig. 1). The axial zone of the basin has a NW-SE orientation and is called the Mid-Polish Trough (MPT). It is a part of the Southern Permian Basin of Western and Central Europe (Ziegler, 1990; Dadlez et al., 2005; Doornenbal and Stevenson, 2010).

The MPT developed along the NW-SE trending Teisseyre-Tornquist Zone during the Permian to Cretaceous (Pożaryski and Brochwicz-Lewiński, 1978; Ziegler, 1990; Dadlez, 1997; Guterch and Grad, 2006); it became filled with a succession of siliciclastic deposoits, carbonates and evaporites (in the Zechstein) several kilometres thick. The Zechstein deposits were buried by Triassic, Jurassic, Cretaceous and Cenozoic strata, while a complex system of more than 90 salt structures evolved simultaneously in the Polish Basin (Dadlez et al., 1998; Krzywiec, 2006). They are of various size and occur in various levels of Mesozoic rocks in which the salt had intruded (Fig. 1). Ten of the salt diapirs cut the upper denudation or structural surface of the Mesozoic, and intrude into the Cenozoic cover.

The Mogilno Salt Dome (MSD) is the only one that reaches the present-day surface. The development of this structure oc-

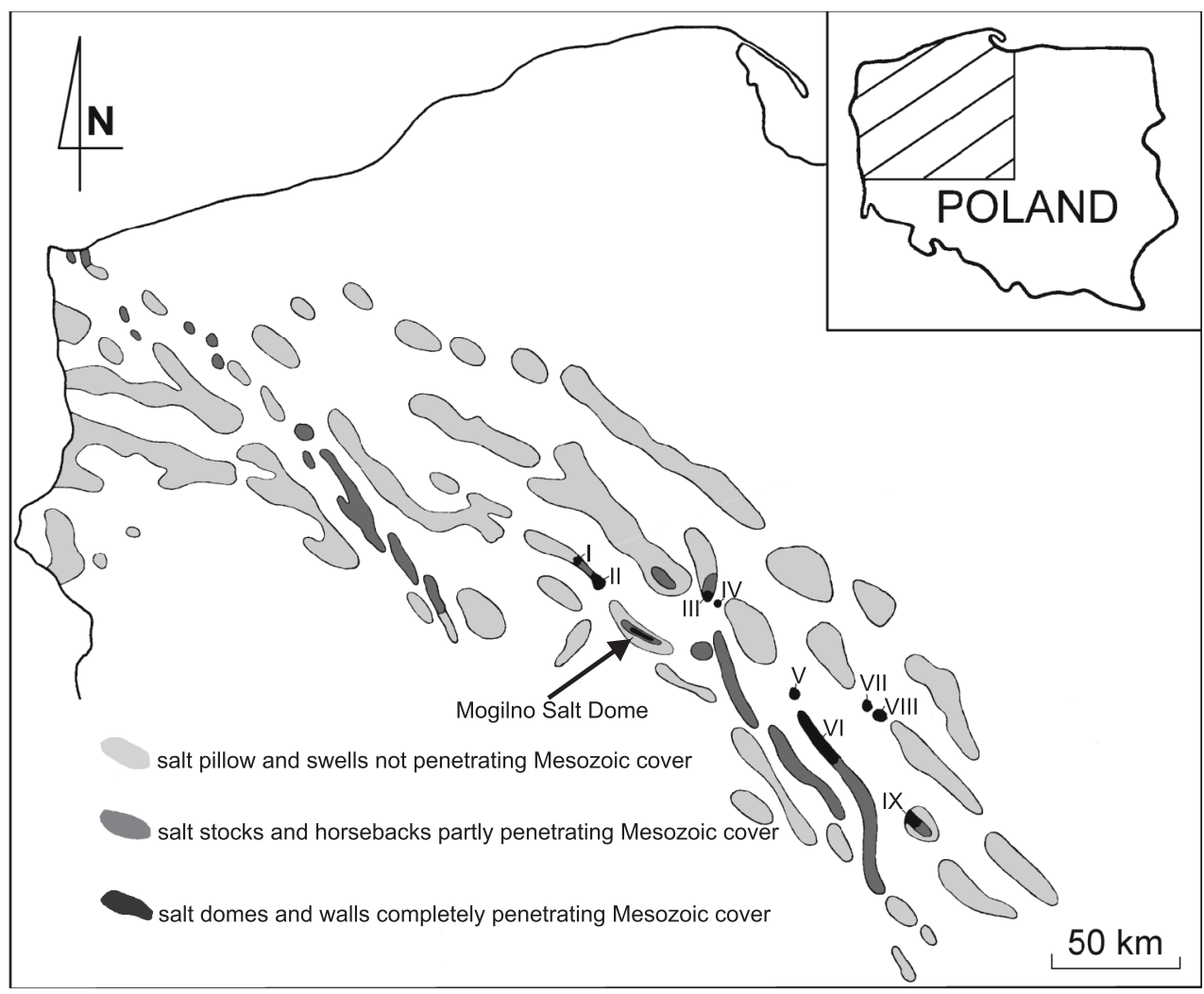

Fig. 1. Location map of the Mogilno Salt Dome and other salt structures in Poland (based on Dadlez, 1997)

I - Wapno Salt Dome, II - Damasławek Salt Dome, III - Inowrocław Salt Dome, IV - Góra Salt Dome, V - Izbica Kujawska Salt Dome, VI - Kłodawa Salt Dome, VII - Lubień Salt Dome, VIII - Łanięta Salt Dome, IX - Rogoźno Salt Dome 


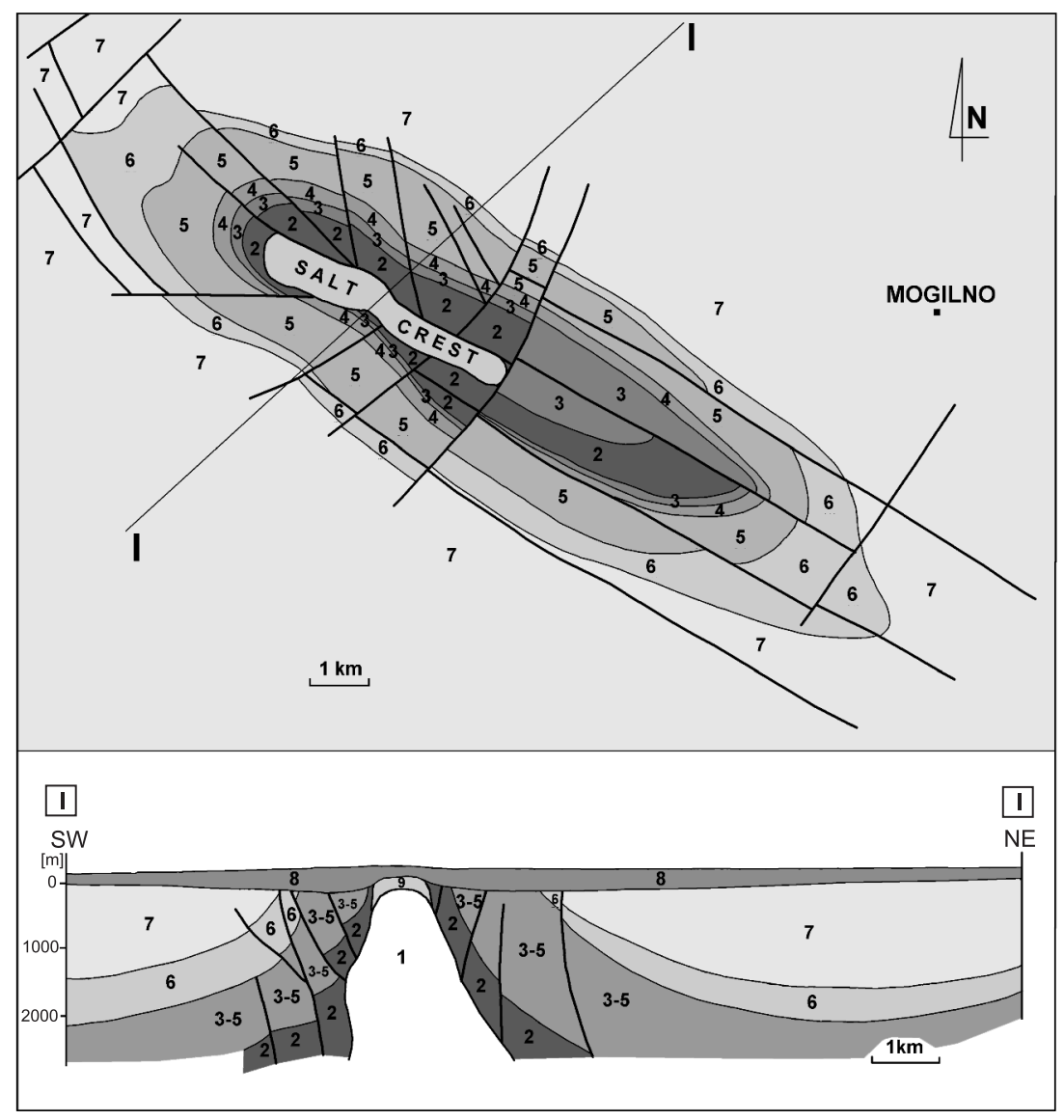

Fig. 2. Geological sketch-map of the Mogilno Salt Dome structure without Cenozoic deposits, with geological cross-section (Wilkosz, 2005, modified after Sokołowski, 1966)

1 - Zechstein rock salt, 2 - Upper Triassic, 3 - Lower Jurassic, 4 - Middle Jurassic, 5 - Upper Jurassic, 6 - Lower Cretaceous, 8 - Cenozoic, 9 - cap-rock

curred in three main phases (Wilkosz, 2005), forming a pillow, a diapir and a post-diapir structure, respectively. Halokinesis started during Mid to Late Triassic times. A thick salt pillow was formed during the Late Triassic to Early Cretaceous. The diapir stage was reached in the Early Cretaceous and diapirism continued during the Paleocene and late Eocene. The post-diapir stage began in the late Eocene to early Oligocene and has continued to the present.

The MSD is located in Central Poland (Fig. 1). It is about $30 \mathrm{~km}$ long, up to $7 \mathrm{~km}$ wide, and up to $6 \mathrm{~km}$ high (Fig. 2); it stretches in a NW-SE direction. At present, this dome is used for gas storage and salt mining (Czapowski and Bukowski, 2010). It is a typical diapir with a central zone where a small salt crest rises up. This asymmetric form is about $5 \mathrm{~km}$ long, and up to $1 \mathrm{~km}$ wide; it intrudes the Cenozoic cover. The salt crest consists of a sequence of PZ2 (Stassfurt) and, on the flanks, PZ3 (Leine) and PZ4 (Aller) deposits. Characteristic of this structure is the vertical arrangement of strata of the three Zechstein salt cycles. The internal structure of the salt body is complex, including folds with vertical, steeply inclined and overturned axes.

The salt crest is surrounded by Triassic, Jurassic and Cretaceous deposits. The Mesozoic deposits in the area of the MSD show a distinct increase in thickness from the centre of the dome to its periphery. Numerous hiatuses occur in the elevated parts of the structure.

The salt crest has a mantle of cap-rock resting on the top of the salt core (Wilkosz, 2005; Wilkosz et al., 2006). This cap-rock varies in thickness, lithology and morphology of the top surface. The irregular topography of the top results in a number of outcrops of the salt crest. The cap-rock immediately under the Cenozoic cover is about $5 \mathrm{~km}$ long and varies in width from 250 to $750 \mathrm{~m}$. Its thickness ranges from 77 to $190 \mathrm{~m}$, most frequently from 130 to $170 \mathrm{~m}$. The upper surface of the cap-rock is undulose, with height differences exceeding $100 \mathrm{~m}$, from $30.4 \mathrm{~m}$ beneath sea level (b.s.l) to $78 \mathrm{~m}$ above sea level (a.s.l.). Two areas, situated in the NW and SE parts of the dome, contain cap-rock above $70 \mathrm{~m}$ a.s.l.; these areas are separated by an area where the central part of the cap has a maximal height of $30.4 \mathrm{~m}$ b.s.l.

The lithology and internal structure are interpreted mainly on the basis of cores from boreholes M III, M IX and M XIII (Fig. 3A, B). On this basis, the following five rock types and deposits building the so-called "gypsiferous cap" covering the salt crest of the MSD have been distinguished. 

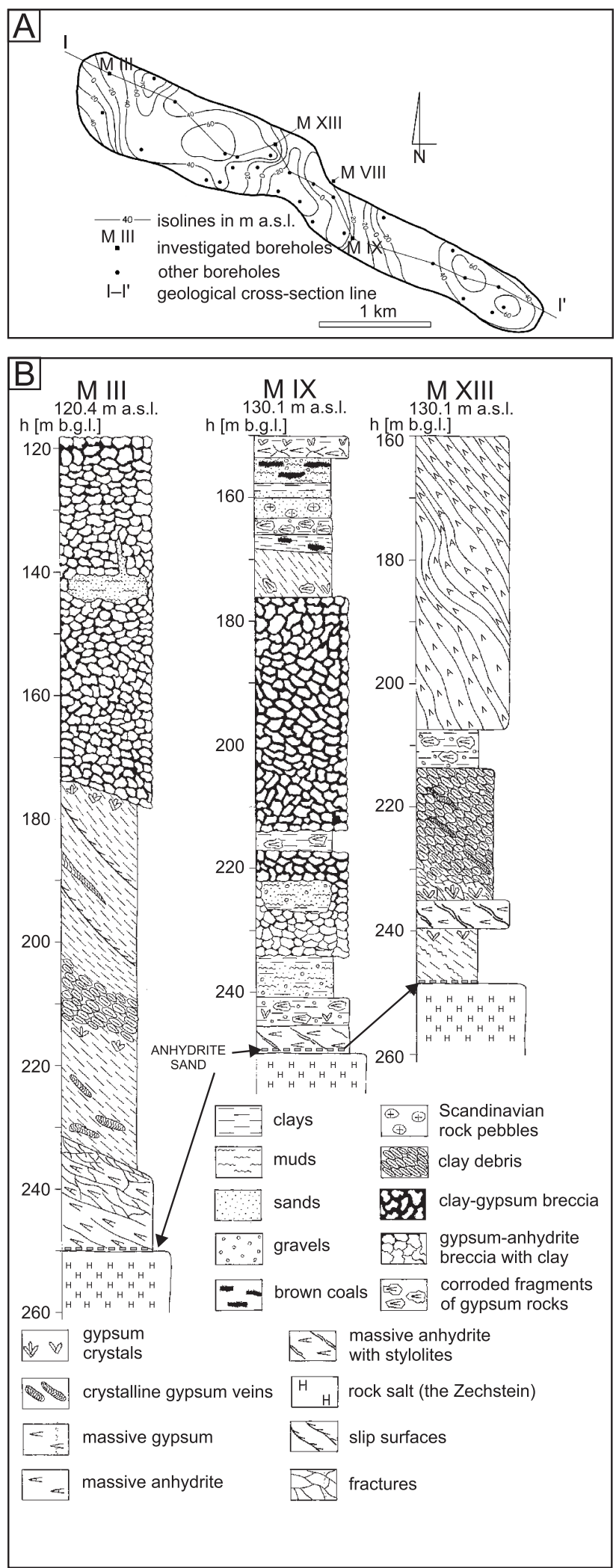

Fig. 3A - topographic surface of the Mogilno Salt Dome cap-rock, with location of the geological cross-section I-I' (Wilkosz, 2001); B - geological profiles of the drill cores from the boreholes M III, M IX and M XIII (Wilkosz, 2005)
1. The main (almost exclusive) component of the cap-rock is gypsum, which occurs in variable shape and size. It forms auto-, hypidio- and xenomorphic crystals, and shows fine-, medium and coarse-crystalline textures. Two specific forms of gypsum are present; lenticular crystals (Fig. 4) and selenite (Fig. 5). Auto- and hypidio-, coarse- to medium-crystalline gypsum dominates near the bottom of the cap-rock, which gradually becomes finer and more xenomorphic upwards.

2. Anhydrite is the main component at the bottom of the cap-rock: it constitutes a layer of anhydrite-bearing sandstone about 20-40 cm thick (Figs. 3B and 4) in boreholes M III, M IX and M XIII, at a depth of 245-250 m below ground level (b.g.l.), just above the salt mirror.

3. Sulphate rocks (Zechstein anhydrites - Fig. 6 - chemically transformed into gypsum in the outer parts of the blocks) are locally intensively corroded and fractured (fractures are frequently healed with gypsum and carbonates). This facies shows a wide array of textures, ranging from cloudy amaeboid-xenotopic with anhydrite relics to idiotopic without anhydrite relics.

4. Sulphate-terrigenous rocks in the form of a breccia of gypsiferous clay (Fig. 7) were formed by complete chemical transformation of anhydrites into gypsum, their secondary dissolution, fracturing and gravitational and tectonic redeposition.

5. Allochthonous fillings of karst caverns, tectonic slits and collapse forms comprising Oligocene sands and muds, Miocene and Oligocene sands and brown coal and Quaternary sands with gravel and small boulders of crystalline rocks.

\section{MATERIAL}

Thirty representative calcium-sulphate core samples (29 gypsum and 1 anhydrite) were analysed for their $\delta^{18} \mathrm{O}$ and $\delta^{34} \mathrm{~S}$ values. They are from three boreholes (Mogilno III, Mogilno IX, Mogilno XIII); 9 samples from Mogilno III, 14 from Mogilno IX and 7 from Mogilno XIII. The samples represent all types of gypsum and derive from depths of the cap-rock from $150.4 \mathrm{~m}$ to $249.5 \mathrm{~m}$ b.g.1. Some samples included carbonate (calcite or magnesite, Fig. 8) and inclusions of anhydrite in the gypsum crystals.

\section{METHODS}

The gypsum samples were analysed for their $\delta^{18} \mathrm{O}$ and $\delta^{34} \mathrm{~S}$ values by Dr. S. Poulson, at the University of Nevada (Department of Geological Science, Reno). The values were measured using an Eurovector model 3000 (elemental analyser to a Micromass IsoPrime stable-isotope ratio mass spectrometer) in a continuous flow mode.

Two methods were applied. The first was used to determine the $\delta^{34} \mathrm{~S}$ value ( $c f$. Giesemann et al., 1994); $\mathrm{V}_{2} \mathrm{O}_{5}$ was added to the sulphate samples as a combustion aid. The values found are expressed in per mil, relative to the Vienna-Canyon Diablo Troilite standard (V-CDT); the analytical precision is $\pm 0.2 \%$. The second method ( $c f$. Kornexl et al., 1999) was used for the $\delta^{18} \mathrm{O}$ analysis; nickelised graphite was added to each sample to promote $\mathrm{CO}$ formation. These values are also expressed in per 


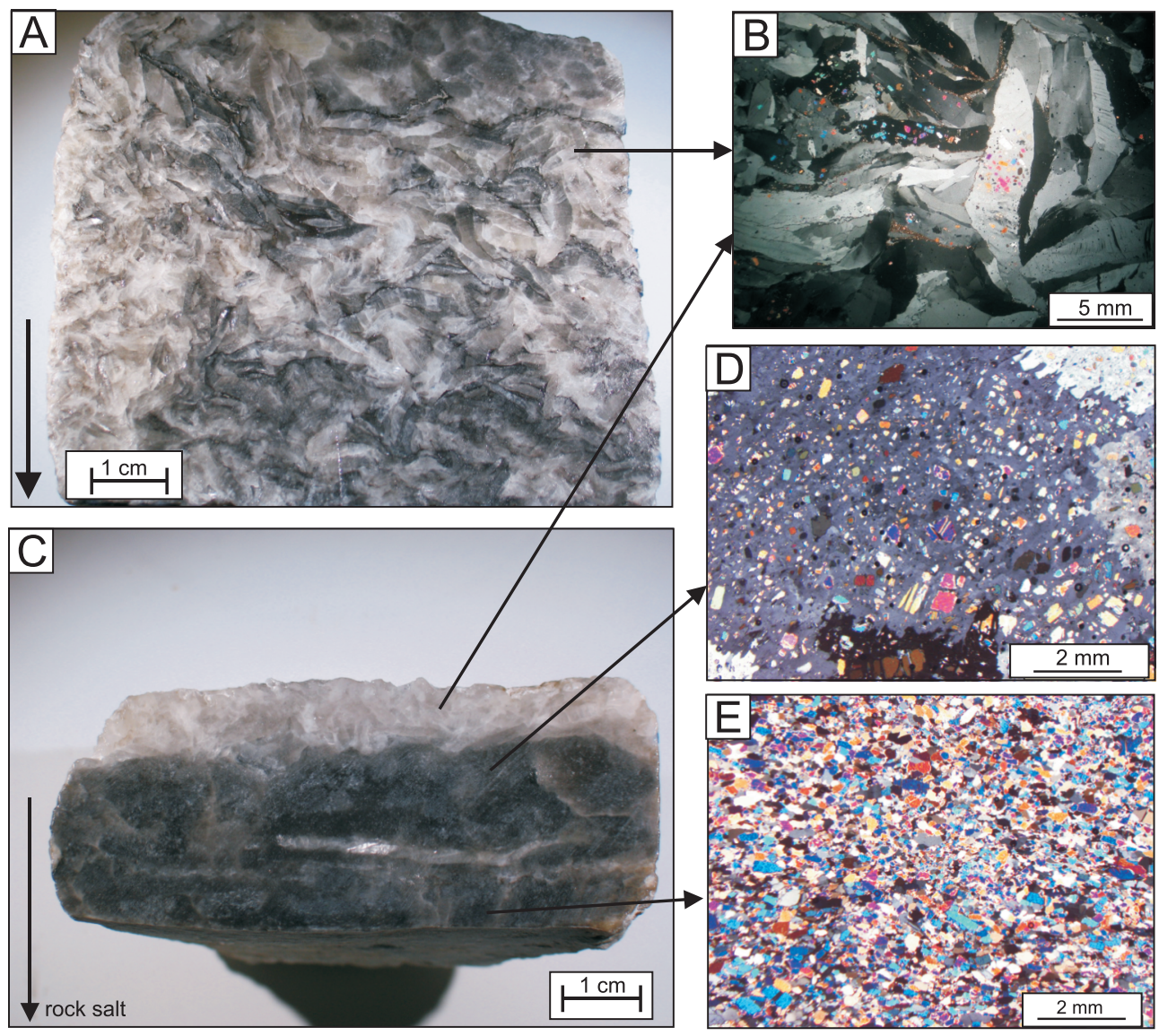

Fig. 4. Micro- and macrophotos of rocks from the contact zone between the salt mirror and the cap-rock

A - lenticular crystals of gypsum (borehole M III, $249.3 \mathrm{~m}$ b.g.1.); B and D - gypsum with anhydrite sand relics (borehole M III, 249.2-249.5 m b.g.1.); C - anhydrite sand from the bottom of the cap-rock directly on the salt mirror (borehole M III, $249.5 \mathrm{~m}$ b.g.1.); E - anhydrite sands level; crossed polars

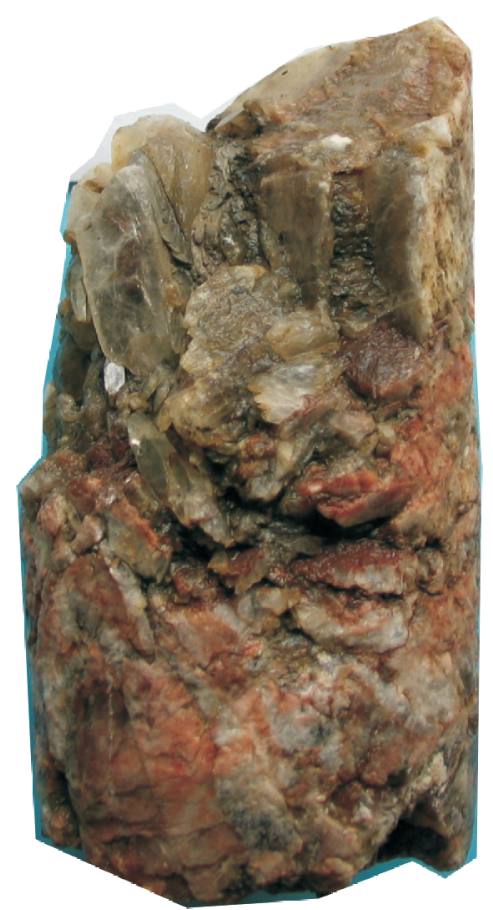

Fig. 5. Selenite gypsum generally occurs in tectonic slits and karstic caves; single crystals have lengths to $10 \mathrm{~cm}$ (M XIII, $237.6 \mathrm{~m}$ b.g.l.) mil, relative to the Vienna-Standard Mean Ocean Water (V-SMOW); the analytical precision is $\pm 0.4 \%$.

The $\delta^{18} \mathrm{O}$ values were measured twice for both the bulk sample $\left(\mathrm{CaSO}_{4} \cdot 2 \mathrm{H}_{2} \mathrm{O}\right)$ and for its dehydrated form $\left(\mathrm{CaSO}_{4}\right.$ residue after dehydration). The isotopic composition of the oxygen in the bulk sample $\left(\mathrm{CaSO}_{4} \cdot 2 \mathrm{H}_{2} \mathrm{O}\right)$ is a mixture of $\delta^{18} \mathrm{O}$ from the $\mathrm{SO}_{4}$ and from the $\mathrm{H}_{2} \mathrm{O}$ (crystallisation water). In order to investigate the differences of the $\delta^{18} \mathrm{O}$ content in both components, the gypsum powder was therefore slowly heated (to eliminate water) under vacuum to $450^{\circ} \mathrm{C}$ for 30 minutes (see: Dowuona et al., 1992). The $\delta^{18} \mathrm{O}$ values in the dehydrated form in $\mathrm{SO}_{4}$ were measured directly by mass spectrometry, whereas the isotopic composition of the water of crystallisation was determined indirectly, by calculating the mean $\delta^{18} \mathrm{O}$ value of the bulk gypsum sample $\left(\mathrm{CaSO}_{4} \cdot 2 \mathrm{H}_{2} \mathrm{O}\right)$ and its $\mathrm{SO}_{4}$ component (from the residue after dehydration). The results obtained using the indirect method have not been verified by a direct method.

\section{RESULTS}

\section{SULPHUR}

The $\delta^{34} \mathrm{~S}$ values in the gypsum cap-rock samples investigated show a range from 10.9 to $13.6 \pm 0.2 \%$ and thus indicate 

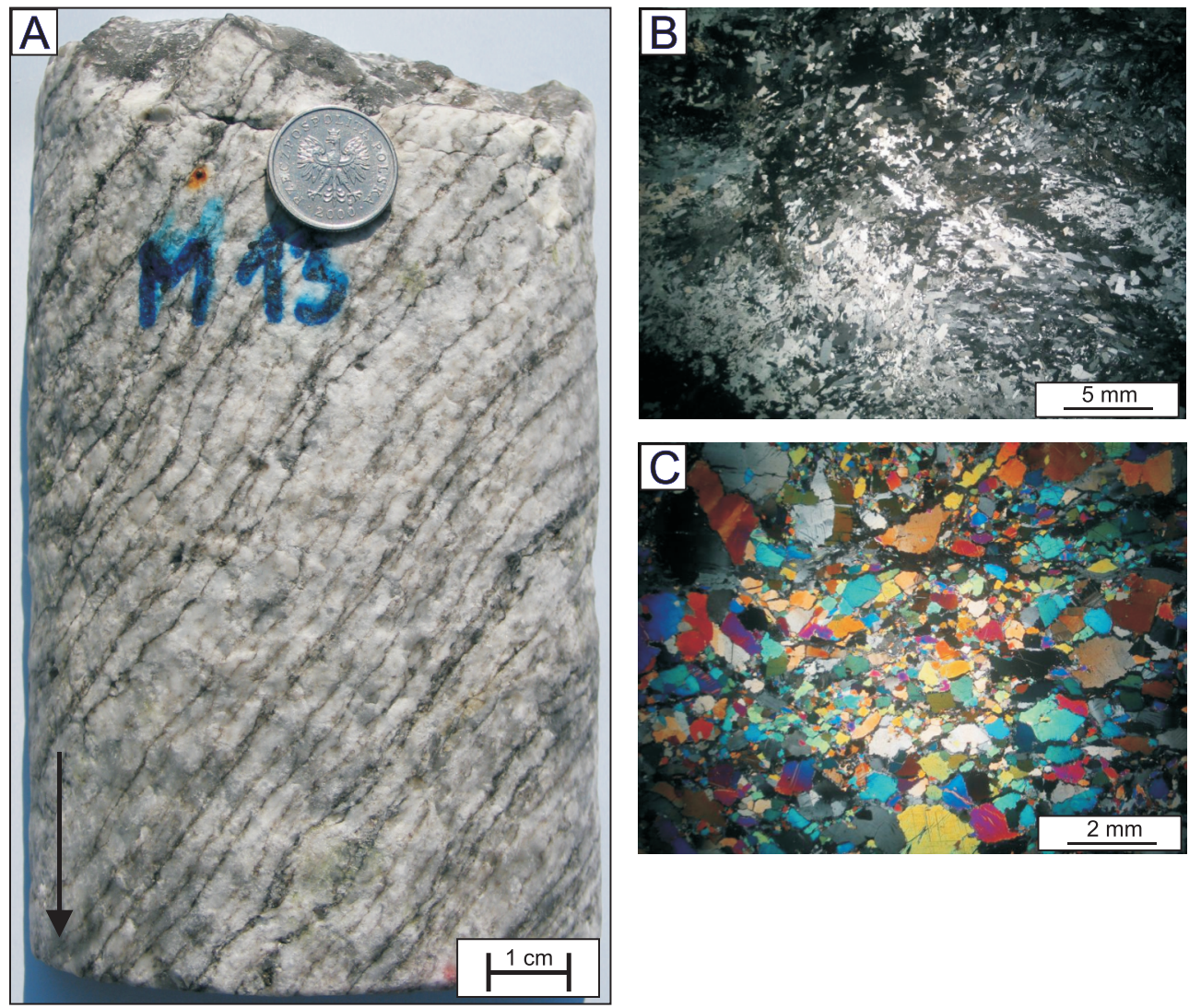

Fig. 6. Zechstein anhydrite (M XIII, $192 \mathrm{~m}$ b.g.I.)

$\mathbf{A}$ - detached block of Main Anhydrite incorporated in the cap-rock; $\mathbf{B}$ - the outer parts of the block are completely transformed into gypsum, $\mathbf{C}$ - in the central parts of the block anhydrites relics are preserved; crossed polars
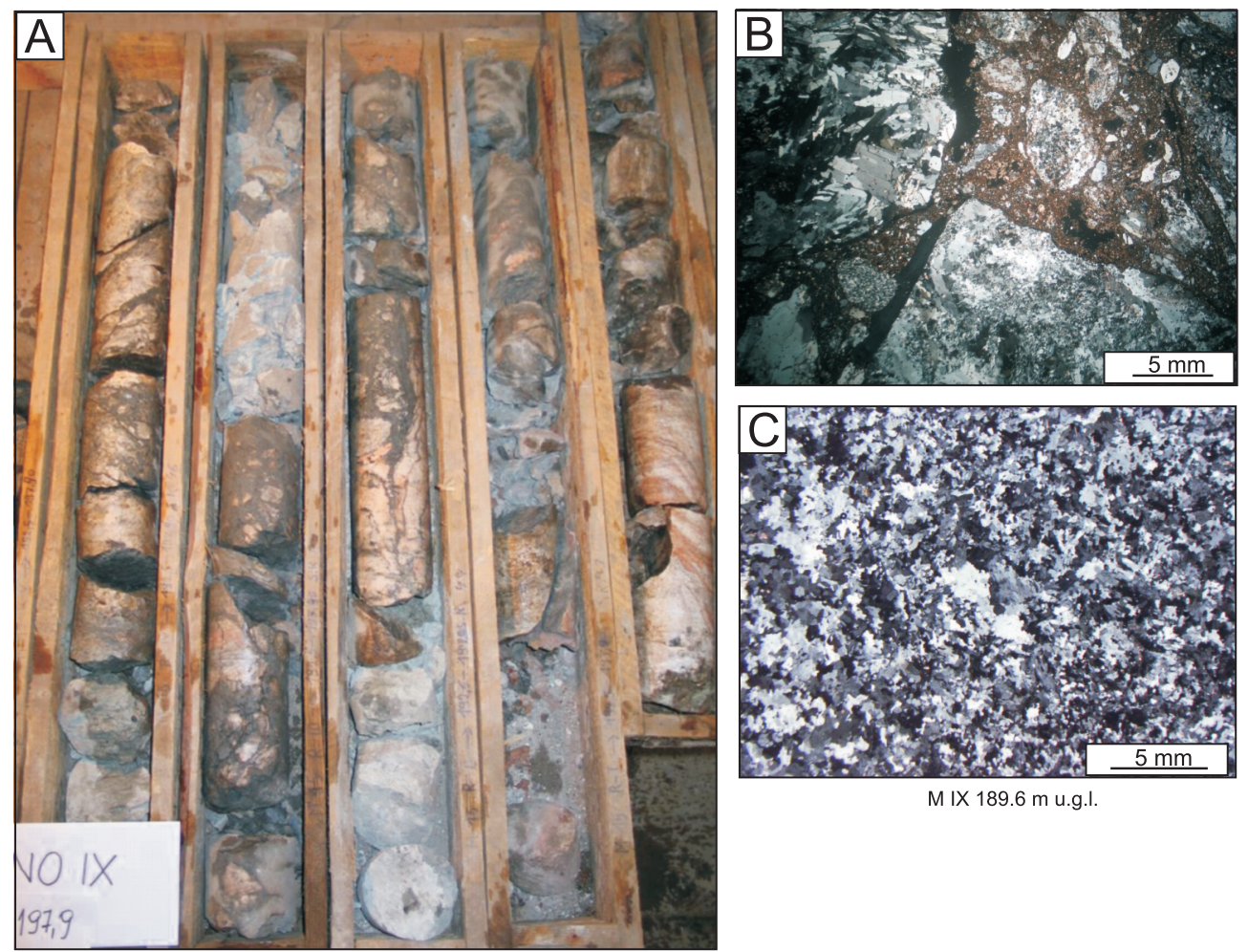

M IX 189.6 m u.g.

Fig. 7. Breccia of sulphate rocks (A) - M IX, 192.6-197.9 m b.g.l.;

B, C - blocks of gypsum rock, clay and mud material; crossed polars 

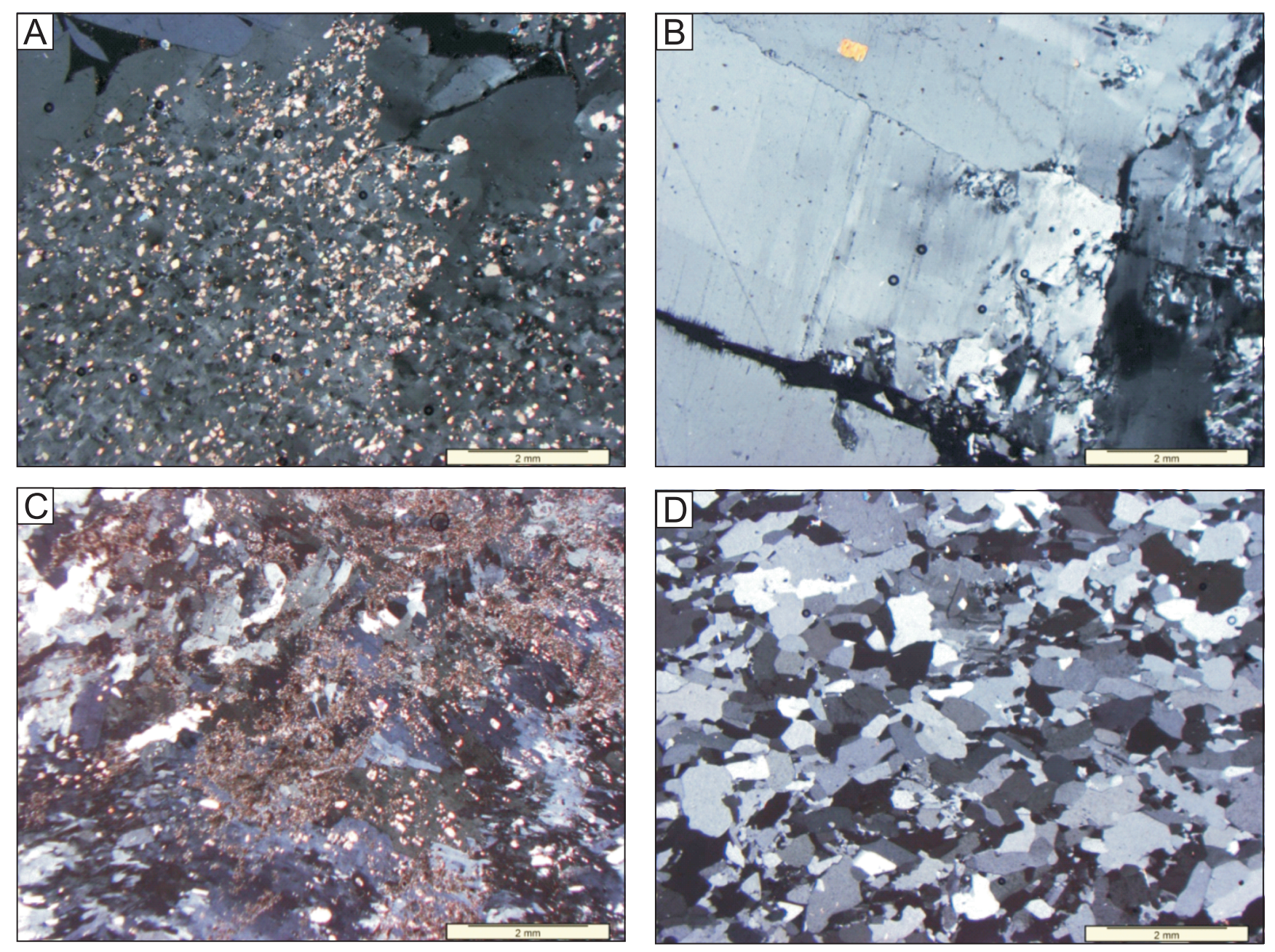

Fig. 8. Microphotos from thin sections of gypsum samples

A - lenticular gypsum with calcium (3-5\% ), M IX, 153 m b.g.l.; B - lenticular gypsum without calcium, M IX, 153.5 m b.g.l.; C - fine-crystalline gypsum with magnesite (10\%), M XIII, $174.1 \mathrm{~m}$ b.g.1.; D - fine-crystalline gypsum with magnesite (1\%), M XIII, 198.1 m b.g.1.; crossed polars

that these sulphates are distinctly enriched - with respect to $\mathrm{V}-\mathrm{CDT}$ - in the heavy isotope; the mean $\delta^{34} \mathrm{~S}$ value is $11.9 \%$ for the core samples from Mogilno III, 11.8\%o for the core samples from Mogilno IX and 11.6\% for the core samples from Mogilno XIII (all $\pm 0.2 \%$; Table 1 ).

\section{OXYGEN}

The $\delta^{18} \mathrm{O}$ values for the $\mathrm{SO}_{4}$ from the gypsum samples range from 11.0 to $14.6 \%$; the mean $\delta^{18} \mathrm{O}$ value is $13.5 \%$ for the core samples from Mogilno III, 13.0\%o for the core samples from Mogilno IX and $13.1 \%$ for the core samples from Mogilno XIII.

The $\delta^{18} \mathrm{O}$ values for the water of crystallisation from the gypsum samples are highly variable and range from -11.3 to $10.7 \%$; their mean $\delta^{18} \mathrm{O}$ value is $-4.9 \%$ o $(-5.7 \%$ if the two gypsum samples enriched in anhydrite are excluded) for the core samples from Mogilno III, $-4.8 \%$ o (-6.0\%o if the sample of anhydrite sandstone is excluded) for the core samples from Mogilno IX and $-8.3 \%$ for the core samples from Mogilno XIII (Table 1).

\section{DISCUSSION}

\section{SULPHUR}

Sulphur isotopes are useful indicators of the origin of sulphates because they preserve their primary isotopic composition very well. Diagenesis (hydration/dehydration), reduction and weathering do not lead to considerable fractionation of the sulphur isotopes; these factors can jointly make a difference only of about $-1.3 \%$, which can commonly be neglected (Holser et al., 1989; Worden et al., 1997; Hoefs, 2004).

The ${ }^{34} \mathrm{~S} /{ }^{32} \mathrm{~S}$ ratio of present-day sulphates (marine evaporites) in oceanic water is fairly constant $(+20 \pm 0.5 \%$ with respect to V-CDT; Pierre, 1988). The fractionation distinguishing dissolved calcium sulphates in oceanic water from gypsum or anhydrite is negligible (Thode and Monster, 1965; Raab and Spiro, 1991), so that recently deposited sulphates in marine evaporite basins have the same $\delta^{34} \mathrm{~S}$ value as the sea water (Claypool et al., 1980). The $\delta^{34} \mathrm{~S}$ values for calcium sulphates in the geological past have changed, but the general trends (S-isotope age curve), including minor oscillations (Nielsen, 
Results of isotope analysis with comments

\begin{tabular}{|c|c|c|c|c|c|c|c|c|}
\hline Sample & $\begin{array}{c}\text { Depth } \\
\text { [m b.g.1.] }\end{array}$ & $\begin{array}{l}\text { Com- } \\
\text { ment }\end{array}$ & $\begin{array}{c}\text { Gypsum- } \\
\delta^{18} \mathrm{O} \text { V-SMOW } \\
{[\% 0]}\end{array}$ & $\begin{array}{c}\mathrm{CaSO}_{4-} \\
\delta^{18} \mathrm{O} \underset{-\mathrm{SMOW}}{\mathrm{V}-\mathrm{SM}]} \\
{[\% \text {. }} \\
\end{array}$ & $\begin{array}{c}\mathrm{H}_{2} \mathrm{O}-\delta^{18} \mathrm{O} \\
{[\% 0]}\end{array}$ & 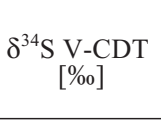 & $\begin{array}{c}\text { Major, minor, trace } \\
\text { components:calcite (C), } \\
\text { magnesite (M), } \\
\text { anhydrite (A) }\end{array}$ & $\mathrm{H}_{2} \mathrm{O}-\delta^{18} \mathrm{O}$ comment \\
\hline \multirow{14}{*}{ M IX } & 150.4 & & 8.4 & 13.6 & -2 & 12.4 & no data & \\
\hline & 152.25 & & 6.8 & 13.3 & -6.2 & 11.7 & no data & \\
\hline & 153 & & 8,1 & 13.8 & -3.3 & 12.2 & $\mathrm{C}-5 \%$ & overstated value \\
\hline & 153.5 & & 7.3 & 13.3 & -4.7 & 12.3 & $\mathrm{C}<1 \%$ & actual value \\
\hline & 175.5 & & 7.1 & 13.6 & -5.9 & 12.1 & $\mathrm{C}, \mathrm{A}<1 \%$ & actual value \\
\hline & 180.7 & & 7.3 & 13.8 & -5.7 & 13.6 & no data & \\
\hline & 183.1 & & 7,1 & 14.6 & -7.9 & 11.6 & no data & \\
\hline & 189.6 & & 5.9 & 12 & -6.3 & 11.3 & - & actual value \\
\hline & 191.1 & & 7.7 & 14 & -4.9 & 11.4 & $\mathrm{C}, \mathrm{M}-10-15 \%, \mathrm{~A}-3 \%$ & problematic \\
\hline & 213.2 & & 5.8 & 12.2 & -7 & 11.5 & $\mathrm{~A}, \mathrm{C}-1 \%$ & actual value \\
\hline & 229.9 & & 6.1 & 12.6 & -6.9 & 11.5 & $\mathrm{C}<1 \%$ & actual value \\
\hline & 249.3 & & 5.5 & 12.6 & -8.7 & 11.3 & $\mathrm{~A}-15 \%$ & overstated value \\
\hline & 249.35 & & 4.5 & 11 & -8.5 & 11 & $\mathrm{~A}-15 \%$ & overstated value \\
\hline & 249.5 & & 11.7 & 12.2 & 10.7 & 10.9 & $\begin{array}{l}\text { anhydrite-bearing } \\
\text { sandstone }\end{array}$ & \\
\hline \multicolumn{3}{|c|}{ Average M IX } & 7.1 & 13 & -4.8 & 11.8 & & \\
\hline \multirow{9}{*}{ M III } & 239.3 & & 6.5 & 12.7 & -5.9 & 11.5 & - & actual value \\
\hline & 240.7 & & 6.3 & 13.3 & -7.7 & 11.6 & - & actual value \\
\hline & 244 & lenticular & 7.9 & 14.6 & -5.5 & 12.4 & - & actual value \\
\hline & 244 & massive & 7 & 13.4 & -5.8 & 11.9 & $\mathrm{~A}-1 \%$ & actual value \\
\hline & 244.3 & & 7.2 & 13.4 & -5.2 & 11.9 & - & actual value \\
\hline & 244.9 & & 7.6 & 13.1 & -3.4 & 11.9 & $\mathrm{C}-5 \%$ & overstated value \\
\hline & 244.9 & & 6.9 & 13.4 & -6.1 & 11.8 & $\mathrm{~A}-30 \%$ & overstated value \\
\hline & 249.5 & lenticular & 7.8 & 14.6 & -5.8 & 12.3 & $\mathrm{~A}-10-15 \%$ & overstated value \\
\hline & 249.5 & massive & 9.3 & 13.1 & 1.7 & 11.6 & $\mathrm{~A}-50 \%$ & high overstated value \\
\hline \multicolumn{3}{|c|}{ Average M III } & 7.4 & 13.5 & -4.9 & 11.9 & & \\
\hline \multirow{7}{*}{ M XIII } & 174.1 & & 5.1 & 13.3 & -11.3 & 11.7 & $\mathrm{M}-10 \%$ & $\begin{array}{c}\text { probably no } \\
\text { influence }\end{array}$ \\
\hline & 175.35 & & 4.8 & 12.6 & -10.8 & 11.5 & $\mathrm{M}-10 \%$ & $\begin{array}{l}\text { probably no } \\
\text { influence }\end{array}$ \\
\hline & 186.2 & & 5.8 & 12.9 & -8.4 & 11.7 & $\mathrm{M}-10 \%$ & $\begin{array}{c}\text { probably no } \\
\text { influence }\end{array}$ \\
\hline & 198 & & 6.1 & 13.5 & -8.7 & 11.6 & $\mathrm{C}-1 \%$ & actual value \\
\hline & 242.7 & & 6.2 & 12.6 & -6.6 & 11.3 & $\mathrm{~A}-1 \%$ & actual value \\
\hline & 242.7 & vein & 6.9 & 13.6 & -6.5 & 11.5 & $\mathrm{~A}-1 \%$ & actual value \\
\hline & 244.8 & & 6.7 & 13.1 & -6.1 & 11.6 & - & actual value \\
\hline \multicolumn{3}{|c|}{ Average M XIII } & 5.9 & 13.1 & -8.3 & 11.6 & & \\
\hline
\end{tabular}

A - anhydrite, $\mathrm{C}$ - calcite, $\mathrm{M}$ - magnesite

1989), are well-known (see Claypool et al., 1980; Holser et al., 1989; Strauss, 1999, 2004).

Zechstein evaporites are characterized by minimum $\delta^{34} \mathrm{~S}$ values for the Phanerozoic (close to $10-12 \%$; see Garcia-Veigas et al., 2011). The values found for the gypsum samples from investigated the Mogilno samples (10.9-13.6\%o) are characteristic of late Permian sulphates; the isotopic composition of the sulphur in these samples $(1.65 \%$ ) reflects, taking into consideration the fractionation factor (Thode and Monster, 1965; Pierre, 1988), the isotopic composition of Zechstein brines. This result is consistent with the sulphur-isotope data for Zechstein evaporites from Northern Germany (9.7-12.6\%: Kampschulte et al., 1998), northeastern Poland (polyhalite)
(10.0-12.1\%; Peryt et al., 2005), southwestern Poland (9.4-13.3\%o; Vovnyuk and Czapowski, 2007) and West Poland (9.6-12.6\% in anhydrite; Peryt et al., 2010).

\section{OXYGEN}

In comparison to the sulphur analysis, the oxygen-isotope composition of gypsum is complex, because it consists of two "kinds" of oxygen: from $\mathrm{SO}_{4}$ (sulphate ion) and $\mathrm{H}_{2} \mathrm{O}$ (water of crystallisation). Both calcium sulphates and their crystallisation water are commonly formed in isotopic equilibrium with the mother brine (Sofer, 1978), but this may change during 
diagenesis. The rate of isotope exchange between a sulphate $\left(\mathrm{SO}_{4}\right)$ and surrounding water is extremely low (Lloyd, 1968; Holt and Kumar, 1991), so that the isotopic composition in sulphate ions is quite stable; it barely changes and remains in equilibrium with the mother brine of the directly precipitated calcium sulphate.

It is different for the water of hydration. Gypsum easily loses its original water of crystallisation during contact with sea water or groundwater. Recrystallisation, dehydration and hydration (sometimes repeated) affect the primary isotopic composition of the gypsum crystallisation water due to diffusion of water of whatever origin (meteoric, open-marine, interstitial brine or a mixture of these) into the crystal. Changes in the $\delta^{18} \mathrm{O}$ value of the water of crystallisation of calcium sulphates may thus originate from the absorption of "new" water.

Modern ocean water contains sulphates of which the $\delta^{18} \mathrm{O}$ values amount to $9.5 \pm 0.5 \%$ with respect to $\mathrm{V}$-SMOW (Longinelli and Craig, 1967). During recrystallisation of oceanic sulphates, the $\delta^{18} \mathrm{O}$ value rises by $3.5-3.6 \%$ (the fractionation factor; Lloyd, 1968; Pierre, 1988) with respect to the mother water; the gypsum water of hydration is then enriched by about 4.0\% (Gonfiantini and Fontens, 1963). This implies that the $\delta^{18} \mathrm{O}$ value of evaporites that precipitated from sea water should be $13.0 \pm 0.5 \%$ o (13.5 $\pm 0.5 \%$ o in the crystallisation water of gypsum).

The $\delta^{18} \mathrm{O}$ value of marine sulphates in the geological past has been more stable than that of sulphur. The ${ }^{18} \mathrm{O} /{ }^{16} \mathrm{O}$ ratio in evaporites has changed slightly over geological time and the general trend is known. The resultant O-isotope age curve can be used to determine the time of evaporite precipitation, and Zechstein evaporites show, like the $\delta^{34} \mathrm{~S}$ values, a minimum $\delta^{18} \mathrm{O}$ value for the Phanerozoic, close to $10 \%$ (see Claypool et al., 1980). This is consistent with the oxygen-isotope data for Zechstein evaporites from northeastern Poland (polyhalite) (10.0-13.5\%; Peryt et al., 2005), southwestern Poland (9.4-10.4\%o; Vovnyuk and Czapowski, 2007) and West Poland (9.4-15.5\% in anhydrite; Peryt et al., 2010).

The data shown in Table 1 indicate that the oxygen-isotope composition of sulphate ions $\left(\mathrm{SO}_{4}\right)$ and water of crystallisation $\left(\mathrm{H}_{2} \mathrm{O}\right)$ of gypsum are very different. The $\delta^{18} \mathrm{O}$ value in $\mathrm{SO}_{4}$ from the Mogilno gypsum samples ranges from 11.0 to $14.6 \%$ (Fig. 9). The measured ratio corresponds to the value known for precipitated calcium sulphates in the isolated evaporite basin of the Zechstein sea and demonstrates the marine origin of this salt.

The $\delta^{18} \mathrm{O}$ values in the water of crystallisation from the Mogilno gypsum samples range from -11.3 to $+1.7 \%$ (mostly between -8 and $-5 \%$ ). This gypsum is secondary: it does not consist of primary calcium sulphates that precipitated from solution but rather of hydrated anhydrites; consequently, their water of crystallisation is not in isotopic equilibrium with the mother brine. The variable $\delta^{18} \mathrm{O}$ values of the $\mathrm{H}_{2} \mathrm{O}$ indicate that the calcium sulphates have been in contact with non-marine (meteoric and/or ground) water that was enriched in light isotopes during the various stages of diagenesis that formed the cap-rock.

The Mogilno cap-rock formed from the Cretaceous on, when the salt intruded the Mesozoic overburden, reaching the zone of percolating groundwater. The salt then started to go into solution, and the residue (anhydrite sand) started to trans-

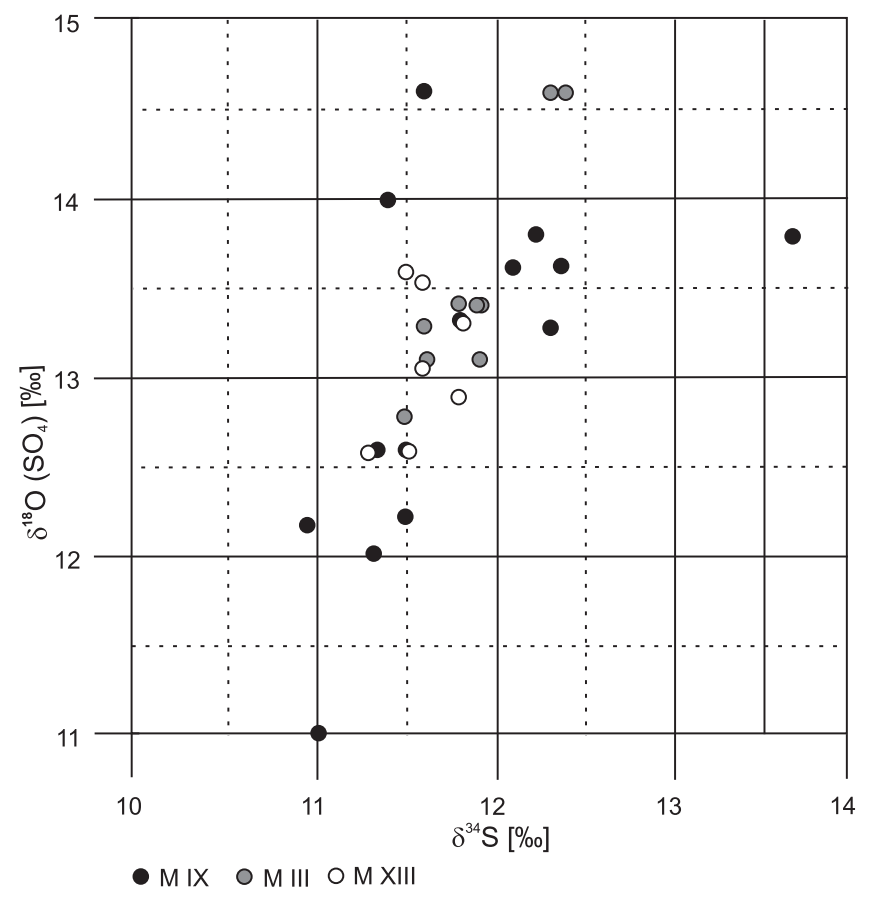

Fig. 9. Values of $\delta^{34} \mathrm{~S} v s$. $\delta^{18} \mathrm{O}$ of residual sulphate depth - 191.1 (m b.g.l.)

form into gypsum. The formation of the incipient cap-rock continued and karst processes affected the material during that time-span; this enabled "new" water, from the surface or the surrounding diapir, to penetrate the cap-rock and the gypsum underwent recrystallisation; the water of hydration then reached a new equilibrium. An assumption has been made that in the case of the gypsum samples, the crystallisation water $\delta^{18} \mathrm{O}$ values correspond to the meteoric water $\delta^{18} \mathrm{O}$ values; the sulphates underwent hydration under the influence of meteoric water, and therefore the crystallisation water of gypsum is in isotope equilibrium with the meteoric water.

Analyses of the crystallisation water of the gypsum from the Mogilno cap-rock give results that are comparable to those of the analyses of water of crystallisation from the cap-rock of the Gorleben Salt Dome (Herbert et al., 1990), where the $\delta^{18} \mathrm{O}$ values in the $\mathrm{H}_{2} \mathrm{O}$ of the gypsum samples range from -12.4 to $-5.2 \%$, and of the Wapno Salt Dome (Jaworska, 2010), where the $\delta^{18} \mathrm{O}$ values in the $\mathrm{H}_{2} \mathrm{O}$ of the gypsum samples range from -13.1 to $-5.6 \%$.

In the Polish Lowland area, the mean isotopic composition of oxygen in modern meteoric water and in recent infiltration water ranges, as a rule, from -10.2 to $-9.2 \%$ (d'Obryn et al., 1997; Duliński et al., 1997). During ancient times of low temperatures such as the Pleistocene, as well as immediately after cold intervals, the groundwater (derived from melt water) was enriched in the light oxygen isotope, so that its $\delta^{18} \mathrm{O}$ values were more negative than those of the water from warm and hot times such as the Paleogene and Neogene, when the groundwater became enriched in the heavy oxygen isotope (Duliński et al., 1997). The stable-isotope composition of water collected from the Mogilno boreholes shows a significantly larger enrichment in the heavy oxygen isotope than is to be expected for infiltration water in this part of Poland (Górski and Rasała, 
2008). The $\delta^{18} \mathrm{O}$ values of water from the $\mathrm{Kg}-1$ and $\mathrm{Kp}-2$ boreholes were (in 2005) -4.3 and $-6.6 \%$ with respect to $\mathrm{V}-\mathrm{SMOW}$, accordingly.

The $\delta^{18} \mathrm{O}$ analyses (using the indirect method) of water of crystallisation in the Mogilno gypsum samples suggest the following five groups of calcium sulphates (Fig. 10):

1. Two samples in which the $\delta^{18} \mathrm{O}$ values of the $\mathrm{H}_{2} \mathrm{O}$ are less than $-10.2 \%$; this gypsum was recrystallised in the presence of water enriched, in comparison to recent meteoric water, in the light isotopes of oxygen. This implies that these gypsum samples (i.e., this part of the cap-rock) came in contact with water supplied during cooler time-spans such as, possibly, the Pleistocene. The $\delta^{18} \mathrm{O}$ values of this crystallisation water probably reflect the ${ }^{18} \mathrm{O} /{ }^{16} \mathrm{O}$ ratio of postglacial meltwater;

2. A group of 15 samples in which the $\delta^{18} \mathrm{O}$ values of $\mathrm{H}_{2} \mathrm{O}$ range between -6.6 and $-4.4 \%$; this gypsum was recrystallised in the presence of water from the cap-rock and has reached isotopic equilibrium with this water;

3. One single analysis of the $\delta^{18} \mathrm{O}$ value of the $\mathrm{H}_{2} \mathrm{O}$ amounts to $+10.7 \%$; this value was not found for a true gypsum sample but for a sample of gypsum from the anhydrite sandstone that occurs near the salt mirror; this value therefore does not reflect the real oxygen-isotope ratio of hydration water, but rather the slightly modified/lower isotope ratio from the sulphate ion;

4. A group of 4 samples in which the $\delta^{18} \mathrm{O}$ values of the $\mathrm{H}_{2} \mathrm{O}$ range between -3.4 and $1.7 \%$; these samples represent gypsum with anhydrite, so that the values found do not reflect the real isotope ratio of the hydration water. The $\delta^{18} \mathrm{O}$ values indicate rather a mixture the oxygen-isotope ratio in sulphate ions and the oxygen-isotope ratio in the water of crystallisation of gypsum; in short, the real $\delta^{18} \mathrm{O}$ content is unknown;

5. A group of 8 samples in which the $\delta^{18} \mathrm{O}$ values of the $\mathrm{H}_{2} \mathrm{O}$ range between -8.7 and $-6.9 \%$; these samples are interpreted as either gypsum with an isotopic composition that represents a mixture of water from the cap-rock and water enriched in light isotopes of oxygen (for example recent meteoric water or postglacial water) or gypsum which was formed in a warmer climate than the present one, when the groundwater was slightly enriched in the heavy isotopes of oxygen.

Comparing the data of the cap-rock gypsum isotope composition of the Mogilno Salt Dome with analogous data from the Wapno Salt Dome cap-rock (Jaworska, 2010), it seems that:

- in the gypsum of both cap-rocks the $\delta^{18} \mathrm{O}$ values indicate the involvement of water: (a) mixed, (b) enriched with light oxygen isotope - indicating the presence of water from colder periods;

- nearly half of the gypsum from the Mogilno cap-rock contains crystallisation water which represents the $\delta^{18} \mathrm{O}$ values corresponding to water inside the cap-rock (from -6.6 to $-4.3 \%$ ), while there is practically no gypsum with $\delta^{18} \mathrm{O}$ corresponding to the present water (class of -10.2 to $-9.2 \%$ ); only two samples got close to this value, reaching $-8.7 \%$, while four of eight samples from Wapno contained crystallisation water with $\delta^{18} \mathrm{O}$ values corresponding to the present water; additionally, regarding the samples from Mogilno, the high percent-

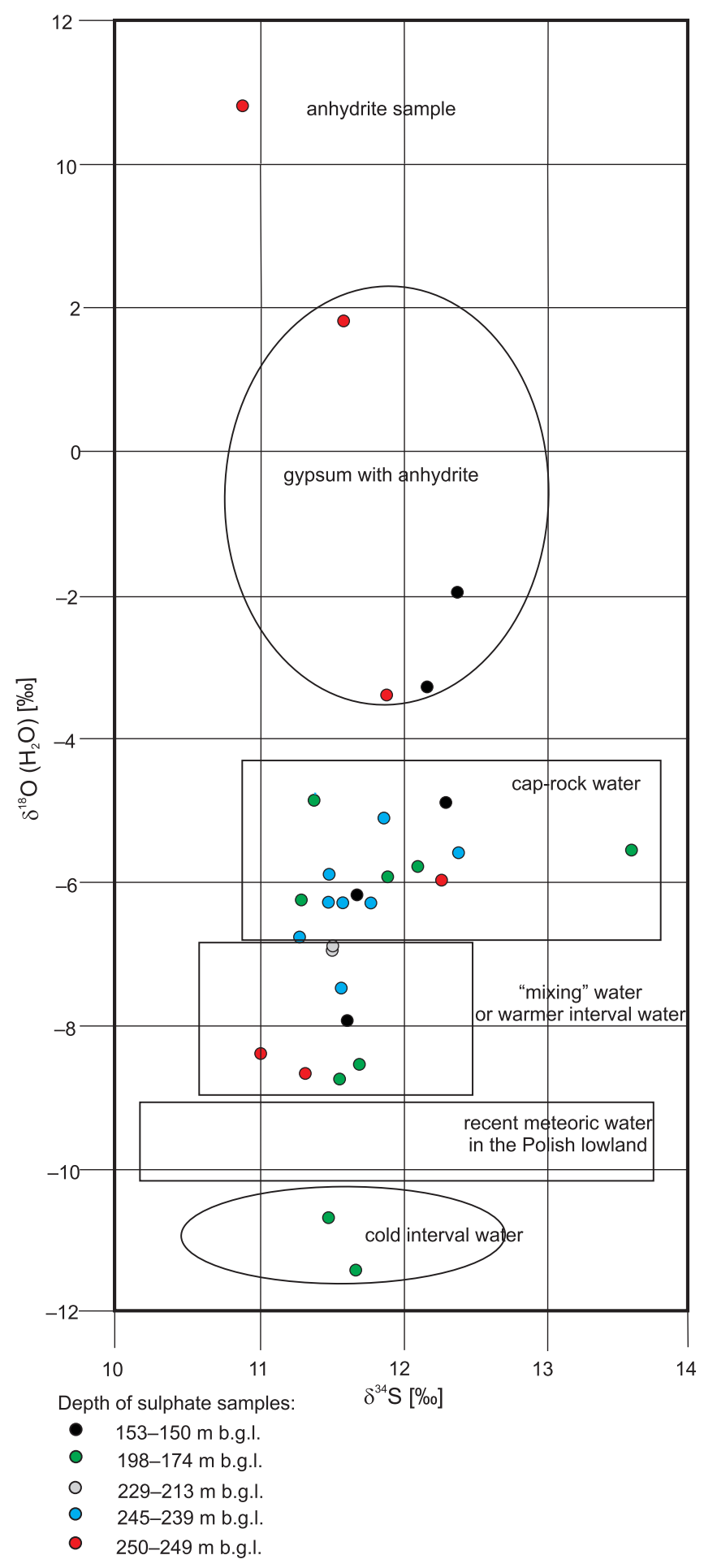

Fig. 10. Values of $\delta^{34} \mathrm{~S} v \mathrm{~s} . \delta^{18} \mathrm{O}$ of water of crystallisation

age of gypsum shows the $\delta^{18} \mathrm{O}$ value slightly enriched in the heavy oxygen isotope (between -8.7 and $-6.8 \%$ );

- gypsum material in samples from Wapno were lacking impurities such as carbonates, so all analyses corresponded to the actual state; in Mogilno, part of the samples contained carbonate impurities, (calcite) or anhydrite, which falsified the proper results. 


\section{SUMMARY}

The gypsum from the cap-rock of the Mogilno Salt Dome is not a primary precipitate from solution but hydrated anhydrite. The oxygen- and sulphur-isotope compositions in the sulphate ion of the gypsum clearly show that sea water/brine is the source of these calcium sulphates. The $\delta^{18} \mathrm{O}$ and $\delta^{34} \mathrm{~S}$ values measured in the $\mathrm{SO}_{4}$ point to the Zechstein evaporite basin as the primary source of these sulphates.

The primary isotopic composition of the $\mathrm{SO}_{4}$ was preserved despite repeated recrystallisation (hydration and dehydration) phases. The isotopic composition of the crystallisation water of this gypsum is a useful diagnostic tool to unravel the diagenetic history of this mineral. Two gypsum samples indicate probably Pleistocene or post-Pleistocene diagenetic processes, because the water of hydration is in equilibrium with water enriched in the light oxygen isotope $(-11.3$ and $-10.8 \%$ ), probably postglacial water. These two gypsum samples come from borehole M XIII, situated near the centre of the cap-rock, at a depth of $174-175 \mathrm{~m} \mathrm{b.g.l}$. (near the surface of the cap-rock) where the gypsum cover is probably cut by fissures that form pathways for circulating water. The cap-rock is in this place quite easily penetrated by water; it is probably "the weakest" point of this cap-rock.

A majority of the gypsum samples crystallised in the presence of water enriched in the heavy oxygen isotope. The $\delta^{18} \mathrm{O}$ values of the crystallisation water can be grouped into two main categories: (1) a group where the values are slightly enriched in the heavy isotopes of oxygen ("mixing" water or water from a warmer interval of time) and (2) a group with water from the cap-rock.

The results of some samples are problematic because these samples show values that are mixtures of real $\delta^{18} \mathrm{O}$ values of crystallisation water and $\delta^{18} \mathrm{O}$ values of impurities in the gypsum samples such as anhydrite and carbonate minerals (see Table 1). The actual isotopic composition of the crystallisation water of these calcium sulphates remains unknown.

The presence of a small percentage of anhydrite impurities in the gypsum samples also suggests that the meteoric water which influenced the sulphates underwent hydration, could not have had free access to the cap-rock, and in reality, the crystallisation water of gypsum had not obtained an equilibrium state with the meteoric water (Bath et al., 1987). Difficult access of the meteoric water to the cap-rock can indicate that the cap-rock in this area has remained an impenetrable body (without larger fractures and joints) - without water circulation and migration routes; and has functioned properly as effective protection for the upper parts of the salt deposit.

One of the main objectives of the study was to test whether the oxygen-isotope ratio of gypsum samples from cap-rock can be measured reliably with the indirect method. It was found that the analysis of pure gypsum samples gives reliable values but that the analytical results of other gypsum samples (gypsum with anhydrite and gypsum with calcite) yield problematic values, which needs to be taken into account when analysing such gypsum samples.

Acknowledgments. The study was supported by grant no. 4T112B03729 from the Polish State Committee for Scientific Research (KBN). The Authors wish to acknowledge Prof. T. van Loon for revision of the previous English draft of this paper and two reviewers: Prof. J. Parafiniuk and Prof. T. M. Peryt for helpful comments and suggestions regarding the manuscript.

\section{REFERENCES}

BATH A. H., DARLING W. G., GEORGE I. A. and MILODOWSKI A. E. (1987) $-{ }^{18} \mathrm{O} /{ }^{16} \mathrm{O}$ and ${ }^{2} \mathrm{H} /{ }^{1} \mathrm{H}$ changes during progressive hydration of a Zechstein anhydrite formation. Geochim. Cosmochim. Acta, 51 (12): 3113-3118.

BORNEMANN O. and BRÄUER V. (1999) - Results of geological investigations at the Gorleben Salt Dome, the potential repository site for radioactive waste in Germany. Radioactive Waste Management and Environmental Remediation - Proc. ICEM'99, Nagoya.

BREWITZ W. and ROTHFUCHS T. (2007) - Concepts and technologies for radioactive waste disposal in rock salt. Acta Montanistica Slovaca, 12 (1): 67-74.

CLAYPOOL G. E., HOLSER W. T., KAPLAN I. R., SAKAI H. and ZAK I. (1980) - The age curves of sulfur and oxygen isotopes in marine sulfate and their mutual interpretation. Chem. Geol., 28: 199-260.

CZAPOWSKI G. and BUKOWSKI K. (2010) - Geology and resources of salt deposits in Poland: the state of the art. Geol. Quart., 54 (4): 509-518.

D'OBRYN K., GRABCZAK J. and ZUBER A. (1997) - Maps of isotope composition of Holocene meteoric waters in Poland (in Polish with English summary). Współczesne Problemy Hydrogeologii: 331-333.

DADLEZ R. (1997) - Ogólne rysy tektoniczne bruzdy środkowopolskiej. Pr. Państw. Inst. Geol., 153: 410-414.

DADLEZ R., MAREK S. and POKORSKI J., eds. (1998) - Atlas paleogeograficzny epikontynentalnego permu i mezozoiku w Polsce 1:2 500 000. Państw. Inst. Geol., Warszawa.
DADLEZ R., GUTERCH A. and GRAD M. (2005) - Crustal structure below the Polish Basin. Is it composed of proximal terranes derived from Baltica? Tectonophysics, 411: 111-128.

DOORNENBAL J.C and STEVENSON A.G., eds. (2010) - Petroleum Geological Atlas of the Southern Permian Basin Area. EAGE Publications b.v., Houten.

DOWUONA G. N., MERMUT A. R. and KROUSE H. R. (1992)-Isotopic composition of hydration water in gypsum and hydroxyl in jarosite. Soil Sc. Soc. Am. J., 56: 309-313.

DULIŃSKI M., GARLICKI A., GRABCZAK J. and ZUBER A. (1997) Badania izotopowe pochodzenia wód w polskich kopalniach soli. Naturalne zagrożenia w kopalniach soli. Materials from the IVth meeting of the Polish Salt Mining Association: 16-27.

GARCÍA-VEIGAS J., CENDÓN D. I., PUEYO J. J. and PERYT T. M. (2011) - Zechstein saline brines in Poland, evidence of overturned anoxic ocean during the Late Permian mass extinction event. Chem. Geol., 290: 189-201.

GIESEMANN A., JAGER H. J., NORMAN A. L., KROUSE H. P. and BRAND W. A. (1994) - On-line sulfur-isotope determination using an elemental analyzer coupled to mass spectrometer. Analytical Chem., 66: $2816-2819$.

GONFIANTINI R. and FONTES J. C. (1963) - Oxygen isotopic fractionation in the water of crystallization of gypsum. Nature, 200: 644-645. 
GÓRSKI J. and RASAŁA M. (2008) - Hydrogeology of the chosen salt domes of the Kujawy region - cognitive and utilitarian aspects (in Polish with English summary). Geologos, 13 (Monographie 5).

GUTERCH A. and GRAD M. (2006) - Lithospheric structure of the TESZ in Poland based on modern seismic experiments. Geol. Quart., 50 (1): 23-32.

HAŁAS S. and KROUSE H. R. (1982) - Isotopic abundances of water of crystallization of gypsum from the Miocene evaporite formation, Carpathian Foredeep, Poland. Geochim. Cosmochim. Acta, 46 (2): 293-296.

HERBERT H.-J., BORNEMANN O. and FISCHBECK R. (1990) - Die Isotopenzusammensetzung des Gipskristallwassers im Hutgestein des Salzstocks Gorleben - ein Nachweis für die elsterzeitliche Bildung der Hutgesteinsbrekzie. Kali und Steinsalz, 10 (7/8): 215-225.

HOEFS J. (2004) - Stable isotope geochemistry (5th ed.). Springer, Berlin Heidelberg, New York.

HOLSER W. T., MAYNARD J. B. and CRUIKSHANK K. M. (1989) Modeling the natural cycle of sulphur through Phanerozoic time. In: Evolution of the Global Biogeochemical Sulphur Cycle (eds. P. Brimblecombe and A. Yu. Lein): 21-56. SCOPE published by John Wiley and Sons Ltd.

HOLT B. D. and KUMAR R. (1991) - Oxygen isotope fractionation for understanding the sulphur cycle. In: Stable Isotopes in the Assessment of Natural and Anthropogenic Sulphur in the Environment (edited by $\mathrm{H}$. R. Krouse and V. A. Grinenko): 27-41. SCOPE published by John Wileyand Sons Ltd.

JACKSON M. P. A. and SENI S. J. (1984) - Suitability of salt domes in the East Texas Basin for nuclear waste isolation: final summary of geologic and hydrogeologic research (1978 to 1983). Univ. Texas, Bur. Econ. Geol., Geol. Circ., 84 (1): 1-128.

JAWORSKA J. (2010) - An oxygen and sulfur isotopic study of gypsum from the Wapno Salt Dome cap-rock (Poland). Geol. Quart., 54 (1): $25-32$.

JAWORSKA J. and RATAJCZAK R. (2008) - Geological structure of the Wapno Salt Dome in Wielkopolska (western Poland) (in Polish with English summary). Pr. Państw. Inst. Geol., 190: 1-69.

KAMPSCHULTE A., BUHL D. and STRAUSS H. (1998) - The sulfur and strontium isotopic compositions of Permian evaporites from the Zechstein basin, northern Germany. Geol. Rundsch., 87: 192-199.

KASPRZYK A. and JASIŃSKA B. (1998) - Isotopic composition of the crystallization water of gypsum in the Badenian of the northern Carpathian Foredeep: a case study from the cores Przyborów 1 and Strzegom 143. Geol. Quart., 43 (3): 301-310.

KLINGE H., KÖTHE A., LUDWIG R.-R. and ZWIRNE R. (2002) Geologie und Hydrogeologie des Deckgebirges über dem Saltzstock Gorleben. Z. angew. Geol., 48 (2): 7-15.

KORNEXL B. E., GEHRE M., HÖFFLING R. and WERNER R. A. (1999) - On-line $\delta^{18} \mathrm{O}$ measurement of organic and inorganic substances. Rapid Communications in Mass Spectrometry, 13: 1685-1693.

KREITLER C. W. and DUTTON S. P. (1983) - Origin and diagenesis of cap rock, Gyp Hill and Oakwood salt domes, Texas. Univ. Texas, Austin, Bur. Econ. Geol., Rep. Invest, 131: 1-55.

KREITLER C. W., COLLINS E. W., FOGG G. E., JACKSON M. and SENI S. J. (1985) - Hydrogeologic characterization of the saline aquifers, East Texas Basin - implications to nuclear waste storage in east Texas salt domes. Univ. Texas, Bur. Econ. Geol., report to US Department of Energy, contract no. DE-AC97-80ET46617.

KRZYWIEC P. (2006) - Triassic-Jurassic evolution of the Pomeranian segment of the Mid-Polish Trough - basement tectonics and subsidence patterns. Geol. Quart., 50 (1): 139-150.

LLOYD R. M. (1968) - Oxygen isotope behavior in the sulfate-water system. J. Geoph. Res., 73: 6099-6110.

LONGINELLI A. and CRAIG H. (1967) - Oxygen-18 variations in sulfate ions and sea water and saline lakes. Science, 156: 56-59.

NIELSEN H. (1989) - Local and global aspects of the sulphur isotope age curve of oceanic sulphates in: Evolution of the global biogeochemical sulphur cycle (ed. P. Brimblecombe and A. Yu. Lein): 57-64. SCOPE published by John Wiley and Sons Ltd.

PERYT T. M., SZARAN J., JASIONOWSKI M., HAŁAS S., PERYT D., POBEREZHSKYY A., KAROLI S. and WÓJTOWICZ A. (2002) -
$\mathrm{S}$ and $\mathrm{O}$ isotope composition of the Badenian (Middle Miocene) sulphates in the Carpathian Foredeep. Geol. Carpath., 53: 391-398.

PERYT T. M., TOMASSI-MORAWIEC H., CZAPOWSKI G., HRYNIV S. P., PUEYO J. J., EASTOE C. J. and VOVNYUK S. (2005) Polyhalite occurrence in the Werra (Zechstein, Upper Permian) Peribaltic Basin of Poland and Russia: evaporite facies constraints. Carbonates and Evaporites, 20 (2): 182-194.

PERYT T. M., HAŁAS S. and HRYNIV S. P. (2010) - Sulphur and oxygen isotope signatures of late Permian Zechstein anhydrites, West Poland: seawater evolution and diagenetic constraints. Geol. Quart., 54 (4): $387-400$

PIERRE C. (1988) - Applications of stable isotope geochemistry to study of evaporites. In: Evaporites and Hydrocarbons (ed. B. C. Schreiber); 300-344. Columbia University Press, New York.

PIERRE C. and FONTES J. C. (1978) - Isotope studies: Isotope composition of Messinian sediments from the Mediterranean Sea as indicators of paleoenvironments and diagenesis. Init. Rep. DSDP, 42 (1): $635-650$

POSEY H. H. and KYLE J. R. (1988) - Fluid-rock interactions in the salt dome environment: an introduction and review. Chem. Geol., 74: $1-24$

POŻARYSKI W. and BROCHWICZ-LEWIŃSKI W. (1978) - On the Polish Trough. Geol. Mijnbouw, 57 (4): 545-557.

PRIKRYL J. D., POSEY H. H. and KYLE J. R. (1988) - A petrographic and geochemical model for the origin of calcite cap rock at Damon Mound salt dome, Texas, U.S.A. Chem. Geol., 74: 67-97.

RAAB M. and SPIRO B. (1991) - Sulfur isotopic variation during seawater evaporation with fractional crystallization. Chem. Geol., 86: 323-333.

SOFER Z. (1978) - Isotopic composition of hydration water in gypsum. Geochim. Cosmochim. Acta., 48: 1141-1149.

SOKOŁOWSKI J. (1966) -The role of halokinesis in the development of Mesozoic and Cainozoic deposits of the Mogilno structure and of the Mogilno-Łódź synclinorium (in Polish with English summary). Pr. Inst. Geol., 50: 1-112.

STRAUSS H. (1999) - Geological evolution from isotope proxy signals sulfur. Chem. Geol., 161: 89-101.

STRAUSS H. (2004) - 4 Ga of seawater evolution: evidence from the sulfur composition of sulfate. Geol. Soc. Am. Spec. Pap., 379: 195-202.

THODE H. G. and MONSTER J. (1965) - Sulfur isotope geochemistry of petroleum evaporites in ancient seas. AAPG Mem., 4: 367-377.

VOVNYUK S. V. and CZAPOWSKI G. (2007) - Generation of primary sylvite: The fluid inclusion data from the Upper Permian (Zechstein) evaporites, SW Poland. Geol. Soc, Spec. Publ., 285: 275-284.

WERNER M. L., FELDMAN M. D. and KNAUTH L. P. (1988) - Petrography and geochemistry of water-rock interactions in Richton Dome cap rock (southeastern Mississippi, U.S.A.). Chem. Geol., 74: 113-135.

WILKOSZ P. (2001) - Geological evolution and kinematics of the Mogilno salt structure in Cainozoic (in Polish). Ph.D. thesis, Institute of Geology, Adam Mickiewicz University, Poznań.

WILKOSZ P. (2005) - Significance of so called „gypsum cap” recognition for safe functioning of underground gas and fuel storage in salt caverns on the examples of the Mogilno and Góra salt structures in: Quo vadis sal. Przyszłość podziemnego magazynowania w złożach solnych. Materials from the Xth meeting of the Polish Salt Mining Association: $40-44$

WILKOSZ P. (2006) - Quaternary Activities of Salt Structures in Poland New Data from the Mogilno Salt Dome. Z. Geol. Wiss., 33 (4/5): 243-261

WILKOSZ P., BURLIGA S., JAWORSKA J. and RATAJCZAK R. (2006) - Tectonic Features within the Cap Rock of the Mogilno Salt Structure, Central Poland. Geolines, 20: 132-133.

WORDEN R. H., SMALLEY P. C. and FALLICK A. E. (1997) - Sulfur cycle in buried evaporites. Geology, 25: 643-646.

ZIEGLER P. A. (1990) - Geological Atlas of Western and Central Europe. Shell Internationale Petroleum Maatschappij B.V.

ZUBER A., GRABCZAK J. and GARLICKI A. (2000) - Catastrophic and dangerous inflows to salt mines in Poland as related to the origin of water determined by isotope methods. Environ. Geol., 39 (3-4): 299-311. 